\title{
EDITORIAL
}

\section{The future of ILAR}

\author{
David A. Fox
}

Received: 3 February 2009 / Accepted: 9 February 2009/Published online: 28 February 2009

(C) Clinical Rheumatology 2009

$\begin{array}{ll}\begin{array}{l}\text { Abbreviations } \\ \text { ACR }\end{array} & \begin{array}{l}\text { American College of Rheumatology } \\ \text { African League Against Rheumatism } \\ \text { AFLAR }\end{array} \\ \text { APLAR } & \begin{array}{l}\text { Asia Pacific League of Associations } \\ \text { for Rheumatology } \\ \text { Community Oriented Program for Control } \\ \text { of Rheumatic Diseases }\end{array} \\ \text { COPCORD } & \begin{array}{l}\text { European League of Associations } \\ \text { of Rheumatology } \\ \text { Outcome Measures for Arthritis Clinical } \\ \text { Trials } \\ \text { OMERAR-American League of Associations } \\ \text { for Rheumatology }\end{array} \\ \text { PANLAR }\end{array}$

Faced with the choice between adaptation and extinction, ILAR has, in the past 2 years, undergone a fundamental metamorphosis. Even ILAR's name is new, albeit with the same initials. No longer the International League Against Rheumatism, ILAR is now the International League of Associations of Rheumatology. From my perspective as Chair of ILAR's Executive Committee in 2008, I will review recent progress and future prospects for the new ILAR.

The initial entity that later evolved into ILAR was known as The International Committee on Rheumatism, and its formation, in 1927, at the International Society of Hydrology meeting in Paris, preceded the existence of national and regional rheumatology societies or leagues [1]. The first President of this new organization was Dr. J

D. A. Fox $(\bowtie)$

The University of Michigan,

3918 Taubman Center, 1500 E. Medical Center Drive, SPC 5358, Ann Arbor, MI 48109, USA

e-mail: dfox@umich.edu
Fortescue Fox of London, England-who is not, to my knowledge, one of my biological ancestors even though he can be viewed as one of my professional forefathers! An office was opened in Amsterdam and within a year a new name was adopted-le Ligue International contre le Rheumatisme. The first journal published by ILAR was Acta Rheumatologica [1]. For decades the ILAR meetings were the primary forum for the international exchange of scientific and clinical information in the field of rheumatology. ILAR developed a productive relationship with the World Health Organization, and more recently with the Bone and Joint Decade and with OMERACT [2, 3]. Importantly, ILAR helped sponsor the COPCORD network, which has conducted community-based studies of the prevalence of rheumatic diseases in many parts of the developing world [2]. In several countries the only available data concerning the epidemiology of arthritis has been generated by COPCORD.

More recently, however, interest in and support for the ILAR meetings waned, as both the ACR and the EULAR congresses grew larger and more international in scope. Fortunately, the publication of Clinical Rheumatology, ILAR's current journal, has continued without interruption, and this may indeed have saved ILAR from disappearing entirely.

After 2 years of planning, 2008 saw the implementation of a new structure and mission for ILAR. The governance of ILAR has been streamlined and is centered on an Executive Committee that is comprised of the President and President-Elect of five rheumatology organizations: AFLAR, APLAR, EULAR, PANLAR (the four regional leagues), and the ACR. The Chair position rotates annually, to ensure an equal role for each member organization. The Executive committee meets twice each year: in early June at the EULAR congress and in the fall at the ACR meeting. 
Administrative support is provided by the American College of Rheumatology through its Atlanta office at no cost to ILAR, and ILAR has therefore been reincorporated as a legal entity in the United States, to where ILAR's funds have also been transferred. A new ILAR Constitution and Bylaws, as well as a Conflict of Interest Policy, have been unanimously adopted. A new 5-year agreement has been reached with the publisher of Clinical Rheumatology that is yielding expanded royalties for ILAR, and the term of the Editor, Paul Davis has been extended. An important activity for the new ILAR will be the cultivation of Clinical Rheumatology as a journal with a uniquely international focus.

International scientific collaboration in rheumatology is now routine and many of the goals of the old ILAR have been fulfilled. But, undeniably, availability of modern treatment for people with rheumatic diseases is shockingly deficient in many of the poorer countries of the world. These inequities are reflected by the lack of adequate numbers of trained rheumatologists and other health professionals with appropriate expertise, and lack of infrastructure for delivery of effective care in many countries.

The paramount goal of the new ILAR is, therefore, to address the global health needs in the rheumatic diseases, with a primary focus on Africa, and on the poorer countries and regions of Latin America, Asia, and the Pacific Rim. As a first step towards this goal, ILAR is now using its funds exclusively for the purpose of supporting specific projects that address clinical needs in rheumatology in the developing world. Although ILAR's currently available funds are modest, the Executive Committee decided in June of 2008 to develop and launch a program of pilot grants for 2009- to clearly demonstrate ILAR's new direction and to begin to catalyze progress in specific areas of the greatest need.

With a short turnaround time for receipt of applications, we wondered whether ILAR's calls for proposals would elicit any interest, but optimistically hoped for perhaps 10 12 proposals. No one expected that ILAR would receive 61 grant applications for the 2009 program, a response that emphatically validated the need for ILAR's new focus on global health.

With many proposals and only $\$ 100,000$ to spend, the decision was unanimously made not to support laboratorybased research or therapeutic trials at this stage, but to focus on pilot projects that will train new personnel, build clinical infrastructure, and engage collaborators from wealthier countries in innovative approaches to rheumatologic health and educational needs in the developing world. In 2009, ILAR is supporting projects in Africa, Latin America, Asia, and also Macedonia (one of the poorest countries in Europe). Several terrific projects could not be funded from the budget available and ILAR hopes to add more new projects in 2010. Clinical Rheumatology could become an important forum for the reporting of results of these ILAR initiatives, once enough data is available.

As progress and successes begin to be documented from ILAR's initial investments, I hope that it will prove possible to attract additional sources of funding from interested foundations and governments. Looking ahead 5 to 10 years, the potential for a robust, thriving, and comprehensive program in rheumatic disease global health — coordinated by ILAR and supported by all organizations in the field of rheumatologyis a vision that can inspire and energize every rheumatologist and every health professional connected to the rheumatic diseases.

It was in 1913 that a Dutch physician, Dr. Jan van Breemen, first articulated the vision of a worldwide effort to study and control the rheumatic diseases, that eventually led to the creation of an international committee in 1927 [1]. Let's do our best to ensure that by 2013, 100 years later, we are well on our way to fulfilling this dream.

Disclosures None.

\section{References}

1. Smyth CJ, Freyberg RH, McEwen C (1985) History of rheumatology in the United States. In: McGuire A (ed) Beginning of the campaign against rheumatism and the formation of the American Rheumatism Association. The Arthritis Foundation, Atlanta, pp 21-36

2. Pfleger B (2007) Burden and control of musculoskeletal conditions in developing countries: a joint WHO/ILAR/BJD meeting report. Clin Rheumatol 27:1217-1227

3. Brooks P, Hochberg M, ILAR and OMERACT (2001) Outcome measures and classification criteria for the rheumatic diseases. A compilation of data from OMERACT (Outcome Measures for Arthritis Clinical Trials), ILAR (International League of Associations for Rheumatology), regional leagues and other groups. Rheumatology 40:896-906 